\title{
Analysis of Vocational School Supervision Planning
}

\author{
Eka Daryanto, Darwin \\ Engineering Faculty \\ State University of Medan \\ Medan, Indonesia \\ ekadaryanto@unimed.ac.id
}

\begin{abstract}
The objective of the research is to know the policies used in determining the need of supervisors in North Sumatera Province. The research also aims to know the process of determining the need of the supervisors. This research uses qualitative approach with descriptive method. The subjects of the research were secretary of educational office, head of human resources planning, school supervisors, principals and teachers. Data collection techniques were observation, interview and documentation. Triangulation data collection techniques were interviews, and documentation studies. The results showed that the implementation of the central and regional policies as the legal basis of the functional position of the supervisor socializes receipt of supervisors through the principal.
\end{abstract}

Keywords—planning, school supervisors, vocational school

\section{INTRODUCTION}

Skills and knowledge are the engines of economic growth and social development of any nation [1], and vocational education holds the key to training the skilled and entrepreneurial workforce needed for the changing technological workforce [2]. Vocational Education is used as a comprehensive term referring to those aspects of the educational process involving, in addition to general education, the study of technologies and related sciences, and the acquisition of practical skill, attitudes, understanding and knowledge related to occupations in various sectors of economic and social life [3].

The effort to improve the quality of human resources starts from the improvement of quality of vocational education. Improvement of the quality of human resources then must be originated from the improvement of quality of education in schools. To maintain and improve the quality of education can be done through the supervision of education. According to Mclean and David [4] Vocational Education is concerned with the acquisition of knowledge and skills for the world of work to increase opportunities for productive empowerment and socio-economic development in knowledge of economics and rapidly changing work environment. Vocational Education thus equips people not only with technical and vocational skills, but also with a broad range of knowledge, skills and attitudes that are now recognized as indispensable for meaningful participation in work and life. The improvement of quality of vocational education requires supervision.

Supervision is a very important stage in processing of organization supervising or control of the implementation of program that has been planned for the achievement of the intended purpose. No. 20 Year 2003 [5], the duties and functions of the Supervisor is based on the Regulation of the Minister of State for Administrative Reform and Bureaucracy
Reform Number 21/2010, in Article 5 which is to carry out the task of academic supervision and managerial supervision on the education unit, covering; Preparation of supervision programs, implementation of supervision, monitoring of the implementation of 8 (eight) National Standards of Education, assessment, guidance and professional training of teachers, evaluation of the results of the implementation of monitoring programs and the implementation of supervisory duties in special areas.

Teacher's task in educating and teaching becomes more strategic in an effort to prepare learners facing the global economic competition entering the era of trade liberalization and especially for the middle level of education, especially vocational education teachers. Vocational school is prepared by the government as an anticipative effort to prevent the gap between educational outcomes and the growing demands of community needs. Vocational education is secondary education that prioritizes the development of students' ability to undertake various works. Vocational secondary education prioritizes the preparation of students to enter employment and develop a professional attitude.

The study of management science is known as a management function consisting of planning, implementation, supervision, and evaluation. Almost all management experts include an element of oversight as a function of management. Robbins and Coulter [6] say that every manager runs five management functions, namely planning, organizing, commanding, coordinating, and controlling. Planning needs of school supervisors is part of human resource planning (HR). Therefore, Mustari [7] says that planning is a series of actions to achieve a desired result through setting the goals, policies, procedures, budgets, and programs of an organization. In fact, there are some vocational schools whose teachers have not been supervised for the last five years. In addition, some vocational supervisors do not even have the same educational background with majors in Vocational High Schools that he coached.

The development of teacher competences are not enough only from within themselves. It also requires a monitoring, motivation, mentoring and guidance from others, especially the principal and supervisor of the school as a more elderly and knowledgeable as well as the highest leaders in the school where he serves. The academic supervision should be implemented to give a significant impact to increase professionalism of teachers.

Based on the various crucial problems that have been described, it is necessary to prepare a careful planning analysis in order to fulfill the need of the Vocational School supervisors. This is to make sure that the result of the 
analysis can be used as the basis for preparing the program of the vocational school supervision. The process of the implementation in this research includes four stages. They are (1) planning stage, (2) implementation stage, (3) identification stage as alternatives and solutions, and (4) implementation of a variety of different impacts caused by the steps was discussed in a row.

\section{METHOD}

This research is a qualitative research with descriptive that can understand human interaction. Data collection techniques were interview, study documentation, and observation. Interviews were conducted with superintendent, school principal, and teachers, secretary of educational office, head of human resources planning, and coordinator of supervisor of vocational school. Triangulation, interviews, and documentation studies were used as data collection techniques.

\section{RESULT AND DISCUSSION}

The local policies used by Vocational Education to plan the needs of the Vocational School supervisors include receiving the school supervisor even though the candidate does not have the certificate of the school superintendent issued by the ministry. In addition, the regional policy is also used in addressing the needs of Vocational High School supervisors, especially in relation to the supervisors of some non-existent cluster subjects, which are enforced by empowering existing supervisors. While the local policies used by Vocational Education to plan the needs of the vocational supervisors include receiving the school supervisor even though the candidate does not yet have the certificate of the school supervisor candidate issued by the ministry.

In addition, in addressing the needs of Vocational School supervisors especially related to supervisors of some of the missing subject groups, the Education Office is wise by empowering existing supervisors. Meanwhile, in meeting the needs of school supervisors Education Office perform recruitment by first doing socialization to teachers who have such qualifications through the principal. This is in line with Sudjana [8] who states that there are 3 minimum criteria to be a supervisor of educational unit, namely a) status as civil servant teacher with minimum working period of 8 years or principal with minimum 4 years of service at education level in accordance with the supervised education unit; $b$ ) have a functional education certificate as a supervisor of the educational unit; c) passed the selection as the educational unit supervisors.

Stages in the recruitment system of school supervisors based on files received from the Secretary of North Sumatra Education Office are as follows.

- Socialization of acceptance of prospective supervisors from the Education Office of North Sumatra Province through Technical Implementation Unit of each District Office to the school.
- The head of the provincial education office receives a file of registration of a prospective supervisor from each Technical Implementing Unit.

- The head of the office shall review and select the completeness of the registration file to determine the eligible candidate.

- Quality Assurance Institution Education shall verify data on the result of the examination of the head of the provincial service office and perform the administrative selection of the prospective supervisor. The results of the verification and selection that have been determined are sent to the Directorate of Education Personnel.

- Eligible candidates will be sent a notification letter from the Directorate of Education Personnel which states that the prospective supervisor is entitled to participate in the selection of supervisors and is required to write a paper on supervision.

- Selection of supervisors shall be conducted by the Directorate of Education Personnel in cooperation with Education Quality Assurance Institution whose implementation can be held at provincial level or Education Quality Assurance Institution.

- The determination of candidates who pass the selection is entirely the authority of the Directorate of Education Personnel.

- The Directorate of Education Personnel proposes the appointment of a supervisor who has passed the selection.

While Sudjana [8] states that the selection of candidates for supervisors is divided into three stages namely.

- Administrative selection; focused on election of school superintendent based on the criteria of administrative completeness including education level, relevance of education program, and certification already owned. The next stage, candidates who pass the administrative selection are grouped by type of school, rank/class, age, and clump subjects (Junior High School-Senior High School-Vocational Secondary).

- Academic selection; done through a test to rank the prospective school supervisor who has passed the academic selection in each group. Forms of test given are (1) Test of early mastery of school supervisor competence; (2) preparing and presenting papers on education / supervisors. Based on the results of the test, then selected candidate of supervisors with the best level in accordance with the number of needs that have been projected. Unelected school election candidates will be included in subsequent recruitment periods (years). Selection is carried out by the education department involving university education, Association of Supervisors throughout Indonesia, and the school supervisor coordinator. 
- Interviews are only given to candidates who have passed the academic selection; to reveal the identity of the school supervisor, the reasons for choosing to be a school supervisor, the perspective supervisor's view of the school supervisor's office, the main tasks and functions of the school supervisor, the future of the school supervisory profession.

What policies are used to determine the needs of Vocational High School supervisors?

In the process of appointing supervisors to obtain qualified supervisors, Vocational School implements some policies, either central or regional policy. The central policies applied are among others Law Number 14 YEAR 2005 regarding teachers and lecturers; Government Regulation, Number 16 YEAR 1994 on the functional position of Civil Servant JO, Number 40 YEAR 2010 amendment to Government Regulation no. 16 of 1994 on functional positions of Civil Servants; Government regulations. Number 99 YEAR 2000 on the promotion of the rank of Civil Servant JO Number 12 YEAR 2003 amendment to Government Regulation No. $99 / 2000$ on the rank assignment of Civil Servants; Government regulations.

Regulation of the Ministry of Administrative Reform and Bureaucratic Reform NO.21 YEAR 2010 concerning functional positions of supervisors and credit scores JO Regulation of the Ministry of Administrative Reform and Bureaucratic Reform No. 14 of 2016 on new rules of functional function of school supervisors and credit scores; JOINT REGULATION The Minister of National Education and the Head of the State Personnel Agency Number 01 / III / $\mathrm{PB} / 2011$ regarding the instruction on the functional position of the teacher and Number 6 of YEAR 2011 regarding the instruction on the function of supervisor and credit number; Regulation of the Minister of Education and Culture Number. 143 YEAR 2014 on technical guidance of functional function of school supervisor; and the Circular Letter of the State Personnel Board and the Minister of Education and Culture No.1 year 2016 on the explanation of the Regulation of the Minister of Administrative Reform and Bureaucracy Reform No. RI. 14 of 2016 on the amendment to the regulation of the Minister of Administrative Reform and Bureaucracy Reform No. 21 of 2010 on the functional positions of school supervisors and credit figures

In the meantime, the local policies used by Vocational school to plan the needs of the Vocational School supervisors include receiving the school supervisor even though the candidate does not have the certificate of the school superintendent inspected by the ministry. In addition, the regional policy is also used in addressing the needs of Vocational School supervisors, especially in relation to the supervisors of some non-existent cluster subjects, which are enforced by empowering existing supervisors. This is evident from the following interview.

Sinulingga: The process is in accordance with applicable terms and policies. Actually, the requirement to become a supervisor is to have a certificate of school supervisor candidate issued by the ministry. But none of them meet the requirements, while the need is there. The need for supervisors exists. So because there is none, then we do.

In addition, the regional policy applied by District is related to the supervisors of several non-existent clumps of subjects, wired with existing supervisors. This is evident from the following interview excerpt.

Sinulingga: The applied policy exists, i.e. policy of the center... we are based on applicable law, also with the area, there must be policy. For example, the regional policy related to the supervisors of some of the missing subject clusters, we must be wise based on the existing supervisors.

Based on the above statement it can be concluded that District in its objective to meet the needs of Vocational School supervisors to implement policies based on applicable laws and local policies made by themselves. Policies are applicable provisions, characterized by consistent and recurrent behaviors both of those who make or carry out those needs, the provisions that make the principles for surrendering a planned and consistent way of acting in achieving a particular goal [9].

The process of Determining the Need of Vocational High School Supervisors.

District, before Vocational School switched to the province, recruited as described [9] stating that there are several steps taken in the school supervisory recruitment system:

- Head of District / Municipality Education Office shall convey information to each Technical Implementing Unit of the Service and each school regarding the recruitment of school supervisors with their qualifications and requirements;

- The Regency / City Education Office receives the enrollment file of the prospective supervisor from each Technical Implementing Unit of the Dinas or the school;

- The District / Municipal Education Office checks and selects the completeness of the registration file consisting of administrative requirements and appendices to determine the eligible candidate;

- Quality Assurance Institution of Education verifies data of inspection result of Head of District / Municipality Education Office in conducting administrative selection of supervisor candidate;

- To the candidate who fulfills all administrative requirements, the Directorate of Education Personnel shall send a notification letter stating that the candidate is eligible to participate in the selection of the supervising candidate and required to write a paper on supervision and submit it to the Directorate no later than one month after receiving notice;

- Selection of supervisors shall be conducted by the Directorate of Education Personnel in cooperation with 
Quality Assurance Institution of Education whose implementation can be held at provincial level or Education Quality Assurance Institution;

- The determination of candidates who pass the selection is entirely under the authority of the Directorate of Education Personnel;

- The Directorate of Education Personnel shall appoint the appointment of a supervisor who has passed the selection, in accordance with the applicable regulations.

Process of Determining Needs of Vocational Secondary School Supervisors at the Provincial Education Office of North Sumatra Post-School Transfer of Management from District / City to Provincial Government

One way to find quality human resources is through the recruitment system. Recruitment is the process of finding and attracting applicants to be employed within organizations [10]. The process of recruiting human resources begins when applicants are sought and terminated when their applications are submitted. The result is a collection of new job applicants to be selected and selected. This process should not be ignored because recruitment is not only looking for good people but also looking for the right person in the job.

Stages in the recruitment system of school supervisors based on files received from the secretary of North Sumatra education Office are as follows.

- Socialization of acceptance of prospective supervisors from the Education Office of North Sumatra Province through Technical Implementation Unit of each District Office to the school.

- The head of the provincial education office receives a file of registration of a prospective supervisor from each Technical Implementing Unit.

- The head of the office shall review and select the completeness of the registration file to determine the eligible candidate.

- Quality Assurance Institution Education shall verify data on the result of the examination of the head of the provincial service office and perform the administrative selection of the prospective supervisor. The results of verification and selection that have been determined are sent to the Directorate of Education Personnel.

- Eligible candidates will be sent a notification letter from the Directorate of Education Personnel which states that the prospective supervisor is entitled to participate in the selection of supervisors and is required to write a paper on supervision.

- Selection of supervisors shall be conducted by the Directorate of Education Personnel in cooperation with Education Quality Assurance Institution whose implementation can be held at provincial level or Education Quality Assurance Institution.
- The determination of candidates who pass the selection is entirely the authority of the Directorate of Education Personnel.

- The Directorate of Education Personnel proposes the appointment of a supervisor who has passed the Selection

\section{CONCLUSION}

Based on research conducted in District Education Office and Education Office of North Sumatra Province can be drawn conclusion as follows,

- In determining the number of Vocational School supervisors Education Office needs to apply policies from the center and from the regions. Policy from the center with reference to several laws as the legal basis for functional position of school supervisor. In the meantime, the local policies used to plan the needs of the Vocational School supervisors include receiving the school supervisor even though the candidate does not have the certificate of the school superintendent inspected by the ministry. In addition, the regional policy is also used in addressing the needs of Vocational School supervisors, especially in relation to the supervisors of some non-existent cluster subjects, which are enforced by empowering existing supervisors.

- Education Office in relation to determine the number of needs of Vocational School supervisors in start by socializing to teachers who have qualified through the principal on terms and recruitment, especially the requirement to have a certificate of prospective supervisor.

- Education Office of North Sumatera Province in determining the need of supervisors of Vocational School to do some things, one of which provides a firm condition in the recruitment of supervisors. Especially the requirement about having a functional certificate, with the number of hours 161 Hours Lesson for the prospective supervisor instead of the number of hours 61 Hours Lessons. However, the reason is still the transition period, while the Provincial Education Office of North Sumatra still provide continuation of duties to the supervisor who was appointed by district / city.

\section{REFERENCES}

[1] Goel, V. P. (2010). Technical and vocational education and training (TVET) system in India for sustainable development. Retrieved March 7 , 2013, http://www.unevoc.unesco.org/up/India_country_paer.pdf from

[2] Afeti, G. (2010). Technical and vocational education and training for industrialization. Retrieved December 23, 2012, from http: //www.arrforum.org/publication/occasional-papers/40/95-technicalandvocational-education-andtrainig-for-industrialisation.html

[3] UNESCO. (2002). Technical and vocational education and training for the twenty first century: UNESCO and ILO Recommendations. Retrieved July 20, 2012, from http://www.google.com.ng 
[4] Mclean, R., \& David, N. W. (2009). International handbook of education for the changing world of work:Bridging academic and vocational learning. Retrieved July 2013, from http://toolkit.ineesite.org/toolkit/INEEcms/uploads/1093/International_H andbook_of_Education_Changing.Pdf.

[5] Regulation of the Minister of State for Administrative Reform and Bureaucratic Reform No. 21 Year 2010, Functional Position of School Supervisor and Credit Numbers, (Jakarta: State Minister of Administrative Reform and Bureaucracy Reform).

[6] Robbins, Stephen P., and Mary Coulter, Management, Tenth Edition, (New Jersey: Pearson Education, 2010).
[7] Mustari, Mohamad, Education Management. Edition1-print 2, (Jakarta: Rajawali Press, 2015).

[8] Sudjana, Nana, Supervisor and Supervision, (Bekasi: Binamitra Publishing, 2012).

[9] Aedi, Nur, Education Supervisors Review Theory and Practice,( Jakarata: Raja Grafindo Persada, 2014)

[10] Sutrisno, Edy, Human Resource Management. Printed 7, (Jakarta: Kencana, 2015). 